\title{
Reliving the past
}

\begin{tabular}{|c|c|}
\hline \multicolumn{2}{|l|}{$\begin{array}{l}\text { Author: } \\
\text { Jurie le Roux }{ }^{1}\end{array}$} \\
\hline \multicolumn{2}{|c|}{$\begin{array}{l}\text { Testament Studies, Faculty } \\
\text { of Theology, University of } \\
\text { Pretoria, South Africa }\end{array}$} \\
\hline $\begin{array}{l}\text { Note: } \\
\text { Prof. Dr Jurie I } \\
\text { emeritus prof } \\
\text { Department o } \\
\text { Studies, at the } \\
\text { Theology, Uni } \\
\text { Pretoria, Pretc } \\
\text { South Africa. }\end{array}$ & $\begin{array}{l}\text { Roux is } \\
\text { ssor in the } \\
\text { Old Testament } \\
\text { Faculty of } \\
\text { ersity of } \\
\text { ria, }\end{array}$ \\
\hline \multicolumn{2}{|c|}{$\begin{array}{l}\text { Correspondence to: } \\
\text { Jurie le Roux }\end{array}$} \\
\hline \multicolumn{2}{|c|}{$\begin{array}{l}\text { Email: } \\
\text { jleroux1@mweb.co.za }\end{array}$} \\
\hline \multicolumn{2}{|c|}{$\begin{array}{l}\text { Postal address: } \\
9 \text { Elephant Road, Monument } \\
\text { Park, Pretoria 0181, } \\
\text { South Africa }\end{array}$} \\
\hline \multicolumn{2}{|c|}{$\begin{array}{l}\text { Received: } 28 \text { May } 2015 \\
\text { Accepted: } 21 \text { June } 2015 \\
\text { Published: } 15 \text { Oct. } 2015\end{array}$} \\
\hline \multicolumn{2}{|c|}{$\begin{array}{l}\text { How to cite this article: } \\
\text { Le Roux, J., 2015, 'Reliving } \\
\text { the past', HTS Teologiese } \\
\text { Studies/Theological Studies } \\
\text { 71(1), Art. \#3058, } 6 \text { pages. } \\
\text { http://dx.doi.org/10.4102/ } \\
\text { hts.v71i1.3058 }\end{array}$} \\
\hline \multicolumn{2}{|c|}{$\begin{array}{l}\text { Copyright: } \\
\text { C 2015. The Authors. } \\
\text { Licensee: AOSIS } \\
\text { OpenJournals. This work is } \\
\text { licensed under the Creative } \\
\text { Commons Attribution } \\
\text { License. }\end{array}$} \\
\hline \multicolumn{2}{|l|}{ Read online: } \\
\hline 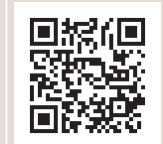 & $\begin{array}{l}\text { Scan this QR } \\
\text { code with your } \\
\text { smart phone or } \\
\text { mobile device } \\
\text { to read online. }\end{array}$ \\
\hline
\end{tabular}

The awareness of the historical nature of our human existence had a profound influence on Old Testament scholarship. The historical nature of the Hebrew Bible was also realised and historical criticism was the result, but in the 20th century there was resistance against this method. This article is an attempt to emphasise the importance of historical understanding as a means of reliving the experiences of others in the present. To illustrate this we focus on the work of Eckart Otto and his exposition of the golden calf narrative in Deuteronomy 9:9-21; $10: 1-5^{*}$. The importance of his work for us lies in his blending of synchrony and diachrony in the study of the book of Deuteronomy.

\section{Introduction}

One of the most profound intellectual developments in the history of hermeneutics occurred at the end of the 18th century when people became aware of the historical character of their human existence (Ankersmit 2007:141). People were convinced that a historical understanding opened up insights 'unprecedented in the Western intellectual heritage, opening a theoretical eye to ... the uniquely individual aspects of the human world' (Barash 2003:xvii). To think and work historically was a special way of discovering these 'uniquely individual aspects of the human world.' This approach penetrated all aspects of research and received the status of 'normal science' (in the Kuhnian sense) (Kuhn 1970:10-42). All scientific inquiry had to take history seriously and even Old Testament scholarship was thoroughly moulded by this historical model of rationality (cf. Thiselton 1980:63-84; Von Harnack 1908:177-179). Historical criticism became the dominant way of understanding the Old Testament, and this could especially be seen in Pentateuch research (Le Roux 1998:477-486).

There was, however, also resistance against this way of thinking. A typical feature of South African biblical scholarship since 1971 was the constant debate about the value of history for the interpretation of the Old Testament. This article attempts to show that despite 'the pastness of the past' the past can still be experienced and can come closer to us (Ankersmit 1990: 102-137; Thiselton 1980:103-113). To illustrate this point we focus on the work of Eckart Otto and especially his two-volume commentary on Deuteronomy (2012a, 2012b) and his exposition of the golden calf narrative in Deuteronomy 9:9-21;10:1-5*. He showed how the text can be read in a synchronical way and still shed light on the context of the exiles. This article is also intended to highlight (in the South African context) the importance of historical investigation as a means of understanding Israel and to relive their true-life experiences.

We begin this article with a brief depiction of the resistance against a historical understanding and a possible way out.

\section{The resistance}

The road that South African biblical scholarship has travelled the past half century is one of constant hermeneutical reflection and intense discussions on theory, exegesis and the understanding of the text. And the terms 'synchrony' and 'diachrony' became central to our biblical scholarship (Le Roux 1993:10-100). They have become the brand names of the endless debates about the value of a diachronical reading of a text and the importance of structural analysis. More often than not diachronical work was often viewed as fleeting, transitory, short-lived and shaky. One of the reasons for this view is that historical facts cannot be retrieved so easily from the text and the original events cannot be described (cf. Otto 2004:14-35).

This suspicion is also part of international Old Testament scholarship of the past decades. In his work on the collapse of history, Perdue refers to the resistance against 'the domination of history (particularly in its positivistic expression) and the historical method in accessing the meaning of 
the Hebrew Bible and birthing of Old Testament theology' (Perdue 2005:4). After World War II the 'voices of discontent', which protested against the Enlightenment strategies for knowing, historical criticism and especially the theologies which were based on them, became louder. These voices grew in numbers and it can be seen in the variety of postcolonialism and liberation theologies, linguistic and narrative approaches, feminist and postmodern interpretations and various ethnic interpretations that emerged (Perdue 2005:6). In short, this reveals a deep distrust in the epistemologies or theories of knowledge of the 19th century and the first half of the 20th century.

In our scholarly community we have also experienced the power of an approach which focussed more on the final text and structural analysis and underplayed historical information. The extra-linguistic world was bracketed and the single sign or word or expression was viewed as sufficient for understanding a linguistic utterance. All that was needed was the correct method and the correct execution of the different exegetical steps (Le Roux 2007:1-18). This synchronic way of working was often viewed as a substitute for historical criticism or diachronic reading.

\section{The past becomes present}

Perhaps we get further if we understand history in terms of recreation, reliving, re-enactment (cf. Gadamer 1990:100110). It remains, however, a major challenge to create a life context from the many different traces in the text and to open up a world wherein the Old Testament can be understood. This is not accomplished by means of a specific method but is dependent on the Old Testament scholar's ability to create a world in which the voices of the past can be heard (Grondin 2002:36-51). History is a creative remaking and retelling of the past. That is, the creative manner in which the scholar arranges and rearranges the relevant information, fits everything into a scheme and finally retells Israel's story in such way that the human struggles of ordinary people and their efforts to formulate their faith and hope, becomes clear (cf. Scharff 2013:122-142).

To accomplish this, the Old Testament scholar must endeavour to penetrate the ideas constituting a specific era or author. Collingwood called it the inner and outer side of an event. One can for instance be interested in the detail of Caesar's crossing of the Rubicon or the precise events surrounding his assassination, but that is not enough. The inside, the thinking behind these events must also be explored. Thus, although the historian usually begins by investigating the outside of an event it never ends there. The historian must take into account that the event was an action and 'that his main task is to think himself into this action, to discern the thought of its agent' (Collingwood 1994:213). Historical understanding implies that the object to be discovered is not the mere event, but the thought expressed in it' (Collingwood 1994:215; cf. Troeltsch 1913:730, 1922: 729-753).
This thought can be found in the ideas of a specific time. Ideas are important because the historical reality or the past is the expression of ideas. Each era also reflects a dominant idea, which permeates all aspects of life and which is the driving force that shapes a society and its people (Ankersmit 1993:176). Only through grasping the leading idea of a specific era can we also understand the unique individual historical phenomena of that era (De Mul 1993:165-166). And this can only be done by means of spiritual empathy (Gunkel 1903:398-455), which enables the researcher to enter into the past, to give it life and blood, and to make the past present.

Another way of saying it is to use the word 're-enactment': Knowledge of the past is gained when the past is re-enacted in the mind of the Old Testament scholar (Ankersmit 1990:79106). We approach the past through ourselves and by means of our prejudices, and through our horizon of meaning we select facts and give meaning to events. And by means of spiritual empathy and imagination we can understand Israel's past and endeavour to make that past present (cf. Eichrodt 1929:983-991).

Historical understanding as recreation or reliving has not always been appreciated in a context where the text was bracketed from the context and structural analysis was viewed as the only way to the understanding of a text. Eckart Otto showed us a way out and below his thoughts are discussed. His work enables us to grasp something of the thinking behind the text and the thoughts expressed in it (cf. Collingwood 1994:213-215; Troeltsch 1913:730; 1922:729-753).

\section{Blending of synchrony and diachrony}

Although the tension between synchrony and diachrony has not been solved in Old Testament scholarship yet (cf. Kilchör 2015:15-17), Otto has incorporated both approaches into a unity. This was a very deliberate decision that can be seen in his exhaustive history of research at the beginning of the first volume of his commentary on Deuteronomy. He did not only highlight the historical critical or diachronic approaches to Deuteronomy but also devoted many pages to a synchronical reading (Otto 2012a:62-230).

One reviewer stated that this commentary 'is unique in its scope and intent'. It is also 'the first commentary on Deuteronomy systematically to combine two hermeneutical perspectives that had seemed for centuries to be separate and irreconcilable streams of exegesis' (Markl 2014:119). Although Otto 'is deeply rooted in the tradition of German Protestant historical critical exegesis' he also:

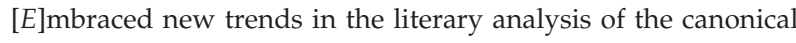
form of the text which have precursors in often polemically anti-critical traditions of 'orthodox' Jewish and Roman Catholic exegesis. (Markl 2014:120)

At the end of his long research history Otto declared that he wanted to emphasise both a diachronic (describing the origin and growth of a text) as well as a synchronical 
approach (taking the final form of the text seriously) (Otto 2012a:230). What Otto proposed is not a new method consisting of definitive steps as we in South Africa have become used to, but a way of thinking of thinking synchrony and diachrony together and to explore their possibilities for the understanding of Deuteronomy and the Pentateuch (Otto 2005:22-49).

\section{The past can give hope}

In Otto's approach text and history are thus not standing over against each other, but the text leads us to a living world where people reflect on God and life. To illustrate this point we are focussing on the narrative of the golden calf in Deuteronomy 9:9-21; 10:1-5* and how the reliving of a much earlier event encouraged the exiles.

According to Otto the book of Deuteronomy had a very long history. It was formed and shaped over more than 300 years ago and the process probably began in the 7th century during the neo-Assyrian rule and the reformation of Josiah; during the exile and the post-exilic times it was thoroughly reworked whilst further additions were made during the Hellenistic era (Otto 1999c:686-693; 2000a:23473; 2012a:231-257). Due to this long literary history many voices from different contexts can be heard in the book of Deuteronomy. Put differently, in the text of Deuteronomy traces of many years of reflection about God and life can be detected (Otto 2007a:19-28). The narrative of the golden calf in Deuteronomy 9:9-21; 10:1-5* is an excellent example of a vibrant theology which is compacted in the text and which reflects the struggles of people during the exile (Otto 1999c:693-696; 2002b:94-14; 2001a:1-188; 2001b:30-40; 2002c:43-83).

Below we highlight the close relationship between the golden calf narrative and the history of Judah. Each time when the story of the calves was being told something was also said about Judah. In pre-exilic times the story has always been told in such a manner that Judah was exempted from the sins of the Northern Kingdom or Israel and therefore would not be punished. After 586 BC and the fall of Jerusalem this storyline had to be changed drastically in order to comfort the exiles in their misery. To illustrate this we briefly refer to three groups of text (Otto 2009:344-352). The first group can be found in the book of Kings (1 Ki 12:28; 2 Ki 17:7-20; 2 Ki 17:21-23) and the second in Exodus 32. Not Exodus 32 in its final form but the first or pre-Deuteronomistic redaction. Then we focus on Deuteronomy 9:9-21; 10:1-5* which is part of what Otto called the Horeb tradition in Deuteronomy 5-11 (Otto 2012a:231-248). All three groups accentuated different shades of meaning regarding the position of Judah during the pre-exilic and exilic era.

Probably 1 Kings 12:28, 2 Kings 17:7-20 and 2 Kings 17:21-23 belonged to the first pre-exilic redaction of the book of Kings and was written from a Judean perspective in an attempt to exempt, or rather absolve Judah from all the gross atrocities of Jeroboam and Israel (Otto 2012b:966-969). According to 1 Kings 12 Jeroboam erected calves in Dan and Bethel and then said:

You have been going up to Jerusalem long enough. Here is your God, who brought you out of Egypt ... and the people went in procession in front of the other one all the way to Dan. (vv. 28-29)

The essence of Jeroboam's apostasy lies in his equation of the calves with the God who led them out of Egypt. Israel followed him in this and this caused their destruction in 722 BC. Judah, however, is not mentioned (Otto 2012b:998-990).

Something similar can be found in 2 Kings 17:21-23. There is an interesting flow of events in these verses. Yahweh tore Israel away from Judah and the people 'had made Jeroboam son of Nebat king'. The Israelites continued with the sin 'which Jeroboam had committed' and 'they did not give it up'. The consequences were severe and at length Yahweh 'thrust Israel away from him' and 'he deported the Israelites from their own country to Assyria, where they have been ever since.' To emphasise the total destruction it is also said that:

[The king] of Assyria brought people from Babylon, Cuthah, Avva, Hamath and Sepharvaim, and settled them in the towns of Samaria to replace the Israelites; these took possession of Samaria and lived in its towns. (2 Ki 17:24)

Once again nothing is said of Judah. The same is true of 2 Kings 17:7-20 which vividly depicts the consequences of Jeroboam's apostasy. The people went much further than Jeroboam and worshiped all kinds of graven images and false gods and therefore their downfall in 722 BC was inevitable. Verse 19 indeed states that Judah also participated, but this is probably a later addition. 2 Kings 17:7-20 therefore also focussed on the abominations of the Northern Kingdom and not Judah (Otto 2012b:965; 2006:71-102).

In the late pre-exilic redaction of the book of Kings, Judah was thus evaluated more positively and this trend was continued in Exodus 32. Underlying this chapter is a preDeuteronomistic narrative which can be found in verses 1a. 4a $\beta$ b. (6) 15a $\alpha, 19 a b \alpha$. 20.30.31ab $\alpha \beta 32,33,35 a b \alpha$ and which also attempted to depict Judah more favourably:

When the people saw that Moses was a long time before coming down the mountain, (they) made the statue of a calf. 'Israel,' the people shouted, 'here is your God who brought you here from Egypt! Early next morning they sacrificed burnt offerings and brought communion sacrifices. The people then sat down to eat and drink, and afterwards got up to amuse themselves. Moses turned and came down the mountain. And there, as he approached the camp, he saw the calf and the groups dancing. Moses blazed with anger. He seized the calf they had made and burned it, grinding it into powder which he scattered on the water, and made the Israelites drink it. On the following day Moses said to the people, 'You have committed a great sin. But now I shall go up to Yahweh: perhaps I can secure expiation for your sin.' Moses then went back to Yahweh and said, 'Oh, this people has committed a great sin. And yet, if it pleased you to forgive their sin ...! If not, please blot me out of the book you have written!' Yahweh said to Moses, 'Those who have 
sinned against me are the ones I shall blot out of my book. And Yahweh punished the people for having made the calf'. (Otto 2012b:959-960)

This pre-Deuteronomistic narrative underlying Exodus 32 is based on 1 Kings 12 and 2 Kings 17:7-20, 21-23: 'Die vordeuteronomistische Erzählung in Ex 32* ist von diesen beiden Jerobeam- Erzählungen literarisch abhängig' (Otto 1996:61-111; 2012b:961). It reworked these chapters and highlighted certain elements. One is the shift from Jeroboam to the people as the real initiators of the building of the calf (Otto 2012b:962). No mention is yet made of Aaron because he only became part of the narrative much later. Another is the intercession of Moses. The remark in 2 Kings 17:18 exempting Judah was reworked in Exodus 32:1-35*, and it is said that only the builders of the calf were to be punished. This punishment in Exodus 32:28 thus refers to Israel and not to Judah. This pre-Deuteronomistic narrative underlying Exodus 32 is therefore not alone an explanation of Israel's downfall but also a sign of hope that Judah would not share the same fate. The Judean theologians must have thought intensely about the consequences of Samaria's fall in 722 BC for Judah and added a 'tiefen' dimension to their story by stating that Judah would be saved (Otto 2012b:965).

The fall of Jerusalem in $586 \mathrm{BC}$ made a radical reinterpretation of 2 Kings 17:7-20, 21-23 and Exodus 32:1-35* necessary. A theology emphasising that Judah would be spared the calamities of Israel was not possible anymore. The Babylonians crushed Judah and Jerusalem and the exiles grappled with important questions. Did the exile imply the end of God's history with his people? In their spiritual odyssey the dates 722 BC (the fall of Israel) and 586 BC (the fall of Judah) haunted them because they were historical markers accentuating defeat, suffering and loss. Would the Babylonian exiles experience the same fate as Israel? Would Judah's identity also be completely destroyed as in the case of the people of Samaria? Would Judah also fade from the pages of history as did Israel? (Otto 2014:141-146). During the exile the authors of the Horeb tradition played a decisive role in reformulating and redesigning the exiles' future and they did that in an ingenious way (Otto 1997:321-339).

In order to answer these questions the authors of the Deuteronomistic Horeb tradition harked back to the event of the golden calf at Horeb, and because they were acquainted with Exodus 32:1-35* they adjusted this narrative to fit their depressing exilic context. Although the new golden calf story in Deuteronomy 9:9-21 and 10:1-5* was based on Exodus $32: 1-35^{*}$ the latter was reinterpreted and a few important changes were made (cf. Otto 1997:321-339). The notion of intercession was taken from the pre-Deuteronomistic narrative in Exodus 32:1-35* but the sequence of events changed. According to this pre-Deuteronomistic narrative Moses came down the mountain, saw the calf and festivities, seized the calf, and destroyed it. Only after that he went back to secure expiation. According to Deuteronomy 9:15-19 Moses noticed the calf and then destroyed the two tablets on which Yahweh wrote the Laws. Yahweh wanted to destroy the people and this filled Moses with great anxiety. He was afraid of Yahweh's fury and fell down and prayed for many days and nights. Only after that did Moses destroy the image (Dt 9:21).

Important is the mention of the tablets and the link that was forged with the Decalogue in Deuteronomy 5:1-22* and the transgression of the First Commandment (Otto 2012b:720-725). The people worshiped other gods and thereby broke the Law and deserved to be destroyed just like Israel in 722 BC. This did not happen due to a sudden turn of events. After Moses' intercession he was instructed to prepare a new set of tablets on which Yahweh could write his Law (Dt 10:1) and this was an indication that Yahweh had changed his mind: 'Die Überwindung des göttlichen Zorns und Vernichtungswillens wird durch JHWH's erneute Beschriftung der zweitn Tafeln ... zum Ausdruck gebracht' (Otto 2012b:965). Furthermore, no mention of punishment is made in Deuteronomy 9:9-21; 10:1-5*. Despite the divine fury and the destruction of the tablets no mention of punishment is made and the conservation of the people was rather emphasised (cf. Otto 1998:876-878; 1999a:625-628; 1999c:693-696; 1999d:1603-1606; 2002b:43-83).

This was an ingenious endeavour by the authors of the golden calf narrative in Deuteronomy 9:9-21; 10:1-5*. According to 1 Kings 12:26-28, 2 Kings 17:7-20 and 2 Kings 17:21-23 as well as the pre-Deuteronomistic narrative underlying Exodus 32 there was hope for Judah because they did not participate in the calf worship and other atrocities of the Northern Kingdom. After 586 BC and the suffering in exile, a different approach had to be followed and in Deuteronomy 9:9-21; 10:1-5* the calf story was reworked in a very creative way: Moses destroyed the original tablets, prayed that Yahweh should not destroy his own people and then Yahweh reissued the laws on two new tablets. And this was the sign that Yahweh would not destroy his own people. The narrative of the golden calf in Deuteronomy 9:9-21; 10:15* thus emphasised that there was indeed hope. Intercession changed Yahweh's intention to destroy all his people and the reissuing of the Commandments stressed that Judah would not share the fate of Israel and be destroyed from the pages of history. The reissuing of the Commandments served as an 'Unterpfand' or guarantee that Yahweh's fury had been changed into salvation:

Wird in der Fabel der erzählten Zeit das Gesetz in Deuteronomyn 12-26 von Mose ... vorgetragen ... so ist das Unterpfand dafür, dass auch in der exilischen Erzählzeit mit der Verlesung des Gesetzes des Deuteronomiums sich der Zorn JHWH's in Heilswillen gewandelt habe. (Otto 2012b:966)

This hope for the future was also strengthened by something else: The Covenant, which has not been broken. On a synchronic level the text of Deuteronomy shows an important difference with the golden calf episode at Horeb. At Horeb the laws were given (cf. Ex 20:18-23:33) and following that event the Covenant was concluded in Exodus 24:1-18*. The breaching of the Covenant in Exodus $32: 1-35^{*}$ thus followed after the making of the 
Covenant in Exodus 24. This first generation at Sinai did indeed break the Covenant; they built the calf and thereby transgressed the First Commandment not to worship other gods. By means of clever ordering of the chapters in the book of Deuteronomy a different story is being told. In Deuteronomy 5 the Commandments were given, in 9:9-10:5 the story of the calf was being told, in Deuteronomy 12-26 the laws of Deuteronomy were communicated and only in Deuteronomy 26:16-17 the Covenant was made. According to this perspective the golden calf episode in Deuteronomy 9:9-21; 10:1-5* took place before the conclusion of the Covenant in Chapter 26. This had major consequences for the addressees of the Horeb tradition. The breaking of the First Commandment in Deuteronomy 9:9-21 and 10:1-5 was indeed a serious transgression but the Covenant had not been broken yet. The addressees in exile knew that the narrative spoke directly to them: 'Die Adressanten des deuteronomistischen Deuteronomiums konnten nach die Katastrophe von 587/586 v.Chr. begreifen, dass diese Erzählung sie betrifft, ja sie in dieser Erzählung vorkommen' (Otto 1999b: 1-84; 2012b:966).

Thus, by means of a radical reinterpretation of pre-exilic texts and the reliving of the events at Horeb the authors of the exile could comfort the exiles with hope for a new future. By means of this desert story the exiles obtained a clearer picture of themselves as well as the unfaithfulness of previous generations (Le Roux 2009:19-32). Through reliving the early history the exiles also comprehended that despite their desperate context a new beginning was possible; that there was a new life after the unfaithfulness of the pre-exilic times; that the laws of Deuteronomy were still valid (cf. Otto 1999e:1-84; 2002a:276-313).

\section{Conclusion}

We began the article by stating the resistance against the historical understanding of texts, but also emphasised a different understanding of history by using the terms 'reliving' and 're-enactment'. Eckart Otto's work can help us to take the final text's embeddedness in life contexts seriously in order to understand the process of reinterpretation and reliving of the past (Otto 2007b:29-53).

To approach a text historically can thus be a rewarding undertaking and at times even an extraordinary experience. When we relive history and re-enact each event in the mind, the past suddenly becomes alive and at times we can even unexpectedly touch something of times gone by. This also happened to the exiles when they relived amidst their bleak conditions an early period in Israel's history. And by means of this reliving of the past they were encouraged to look forward to a new future.

This article is dedicated to my much-respected friend and colleague Pieter de Villiers whom I have known since 1976. We were very young then and part of the historical background group of the New Testament Society of South Africa. Often we have debated the value or non-value of history for biblical scholarship and may this article remind him of those discussions many years ago, but also of what we have accomplished. I wish him all the best and may he enjoy good health and have the strength to keep on working.

\section{Acknowledgements Competing interests}

The author declares that he has no financial or personal relationships which may have inappropriately influenced him in writing this article.

\section{References}

Ankersmit, F., 1990, De Navel van de Geschiedenis, Historische Uitgeverij, Groningen. Ankersmit, F., 1993, De historische ervaring, Historische Uitgeverij, Groningen.

Ankersmit, F., 2007, De sublieme historische ervaring, Historische Uitgeverij, Groningen.

Barash, J.A., 2003, Martin Heidegger and the problem of historical meaning, Fordham University Press, New York, NY.

Collingwood, R.G., 1994, The idea of history, Oxford University Press, Oxford.

De Mul, J., 1993, De tragedie van de eindigheid: Diltheys hermeneutiek van het leven, Kok Agora, Kampen.

Eichrodt, W., 1929, 'Hat die Alttestamentliche Theologie noch selbständige Bedeutung innerhalb der Alttestamentlichen Wissenschaft?', Zeitschrift für die alttestamentliche Wissenschaft 47, 983-991. http://dx.doi.org/10.1515/ zatw.1929.47.1.83

Gadamer, H.G., 1990, Wahrheit und Methode, JCB Mohr, Tübingen.

Grondin, J., 2002, 'Gadamer's basic understanding of understanding', in R.J. Dostal (ed.), The Cambridge companion to Gadamer, pp. 36-51, Cambridge University Press, Cambridge. http://dx.doi.org/10.1017/CCOL0521801931.003

Gunkel, H., 1903, 'The religio-historical interpretation of the New Testament', The Monist 13, 398-455. http://dx.doi.org/10.5840/monist190313331

Kilchör, B., 2015, Mosetora und Jahwetora - das Verhältnis von Deuteronomium 12 26 zu Exodus, Levitikus und Numeri, Harrassowitz Verlag, Wiesbaden.

Kuhn, T.S., 1970, Structure of scientific revolutions, University of Chicago Press, Chicago, IL.

Le Roux, J.H., 1993, A story of two ways, Verba Vitae, Pretoria.

Le Roux, J.H., 1998, 'Israel's past and the feeling of loss. (Or: Deconstructing the "minimum" of the "minimalists" even further', Old Testament Essays 11(3), 477-486.

Le Roux, J.H., 2007, 'Setting the scene: The battle of the signs', in J.H. le Roux \& E. Otto (eds.), South African perspectives on the Pentateuch between synchrony and diachrony, pp. 1-18, T\&T Clark, New York, NY.

Le Roux, J.H., 2009, 'Suffering and hope during the exile', in B. Becking \& D. Human (eds.), Exile and suffering, pp. 19-32, Brill, Leiden.

Markl, D., 2014, 'E. Otto, Deuteronomium 1, 1-4, 43; 4, 44- 1, 32', Biblica 96(1), 119-122.

Otto, E., 1996, 'Die nachpriesterschriftliche Pentateuchredaktion im Buch Exodus', in M. Vervenne (ed.), Studies in the book of Exodus, pp. 61-111, Peeters, Leuven.

Otto, E., 1997, 'Das Deuteronomium als archimedischer Punkt der Pentateuchkritik. Auf dem Wege zu einer Neubegründung der de Wette'schen Hypothese', in J. Lust \& M. Vervenne (eds.), Deuteronomy and Deuteronomic Literature, Festschrift, C.H.W. Brekelmans, pp. 321-339, Peeters, Leuven.

Otto, E., 1998, s.v. 'Bundesbuch', in H.D. Betz \& D.S. Browning (Hrsg.), Religion in Geschichte und Gegenwart, 4th edn., vol. 1, pp. 876-887, Mohr Siebeck, Tübingen.

Otto, E., 1999a, s.v. 'Dekalog I. Altes Testament', in H.D. Betz \& D.S. Browning (Hrsg.), Religion in Geschichte und Gegenwart, 4th edn., vol. 2, pp. 625-628, Mohr Siebeck, Tübingen.

Otto, E., 1999b, Das Deuteronomium: Politische Theologie und Rechtsreform in Juda und Assyrien, Walter de Gruyter, Berlin. http://dx.doi.org/10.1515/9783110802191

Otto, E., 1999c, s.v. 'Deuteronomium', in H.D. Betz \& D.S. Browning (Hrsg.), Religion in Geschichte und Gegenwart, 4th edn., vol. 2, pp. 693-696, Mohr Siebeck, Tübingen.

Otto, E., 1999d, s.v. 'Ethik III. Biblisch, I. AT', in H.D. Betz \& D.S. Browning (Hrsg.), Religion in Geschichte und Gegenwart, 4th edn., vol. 2, pp. 1603-1606, Mohr Siebeck, Tübingen.

Otto, E., 1999e, 'Die Ursprünge der Bundestheologie im Alten Testament und im Alten Orient', Zeitschrift für Altorientalische und Biblische Rechtsgeschichte 4, 1-84.

Otto, E., 2000a, Das Deuteronomium in Pentateuch und Hexateuch: Studien zur Literaturgeschichte von Pentateuch und Hexateuch im Lichte des Deuteronomiumrahmens, JCB Mohr (Paul Siebeck), Tubingen.

Otto, E., 2000b, 'Mose und das Gesetz. Die Mosefigur als Gegenentwurf Politischer Theologie zur neuassyrischen Konigsideologie im 7. Jh. v. Chr.', in E. Otto (Hrsg.), Mose, Agypten und das Alte Testament, pp. 43-83, Verlag Katholisches Bibelwerk, Stuttgart. 
Otto, E., 2001a, 'Die Tora in Max Webers Studien zum Antiken Judentum. Grundlagen fur einen religions- und rechtshistorischen Neuansatz in der Interpretation des biblischen Rechts', Zeitschrift für Altorientalische und Biblische Rechtsgeschichte 7, 1-188.

Otto, E., 2001b, Die Tora des Mose: Die Geschichte der Vermittlung von Recht, Religion und Politik durch die Mosegestalt, Vandenhoeck \& Ruprecht, Göttingen. (Berichte aus den Sitzungen der Joachim Jungius-Gesellschaft der Wissenschaften Hamburg, 19/2).
Hamberis

Otto, E., 2002a, Gottes Recht als Menschenrecht: Rechts- und literaturhistorische Studien zum Deuteronomium, Harrasowitz Verlag, Wiesbaden. (Beihefte zur Zeitschrift für Altorientalische und Biblische Rechtsgeschichte, 2).

Otto, E., 2002b, Max Webers Studien des Antiken Judentums: Historische Grundlegung einer Theorie der Moderne, JCB Mohr (Paul Siebeck), Tübingen.

Otto, E., 2002c, 'Politische Theologie in den Konigspsalmen zwischen Agypten und Assyrien. Die Herrscherlegitimation in den Psalmen 2 und 18 in ihren altorientalischen Kontexten', in E. Otto \& E. Zenger (Hrsg.), 'Mein Sohn bist du' (Ps 2,7). Studien zu den Königspsalmen, pp. 43-83, Verlag Katholisches Bibelwerk, Stuttgart.

Otto, E., 2004, 'The Pentateuch in synchronical and diachronical perspectives: Protorabbinic scribal erudition mediating between Deuteronomy and the Priestly Code', in E. Otto \& R. Achenbach (Hrsg.), Das Deuteronomium zwischen Pentateuch und Deuteronomistischem Geschichtswerk, pp. 14-35, Vandenhoeck \& Ruprecht, Göttingen. http://dx.doi.org/10.13109/9783666530708.14

Otto, E., 2005, 'The Pentateuch between synchrony and diachrony', in E. Otto \& J.H. Le Roux (eds.), A critical study of the Pentateuch: An encounter between Europe and Africa, pp. 22-49, Lit, Münster.

Otto, E., 2006, 'Das postdeuteronomistische Deuteronomium als integrierende Schlußstein der Tora', in M. Witte, K. Schmid, D. Prechel \& J.C. Gertz (Hrsg.), Die deuteronomistischen Geschichtswerke: Redaktions- und religionsgeschichtliche Perspektiven zur Deuteronomismus-Diskussion in Tora und vorderen Propheten pp. 71-102, De Gruyter, Berlin. http://dx.doi.org/10.1515/9783110927344.71
Otto, E., 2007a, 'A hidden truth behind the text or the truth of the text: At a turning point in biblical scholarship two hundred years after De Wette's Dissertation Critico-Exegetica', in J.H. le Roux \& E. Otto (eds.), South African perspectives on the Critico-Exegetica', in J.H. le Roux \& E. Otto (eds.), South African perspectives on the
Pentateuch between synchrony and diachrony, pp. 19-28, T\&T Clark, New York, NY.

Otto, E., 2007b, 'The pivotal meaning of Pentateuch research for a history of Israelite and Jewish religion and society', in J.H. le Roux \& E. Otto (eds.), South African perspectives on the Pentateuch between synchrony and diachrony, Pp. 29-53, $\&$ T perspectives on the Pentateuch between synchrony and diachrony, pp. 29-53, T\&T
Clark, New York, NY.

Otto, E., 2009, 'Die Erzählung vom goldenen Kalb in ihren literarischen Kontexten. Zu einem Buch van Michael Konkel', Zeitschrift für Altorientalische und Biblische Rechtsgeschichte 15, 344-352.

Otto, E., 2012a, Deuteronomium 1-11, 1. Teilband: 1, 1-4, 43, Herder Verlag, Freiburg. Otto, E., 2012b, Deuteronomium 1-11, 2.Teilband: 4, 44-11, 32, Herder Verlag, Freiburg.

Otto, E., 2014, 'Deuteronomiumstudien IV: Das nachexilische Deuteronomium: Ein prophetisches Buch', Zeitschrift für Altorientalische und Biblische Rechtsgeschichte $20,141-146$.

Perdue, L.G., 2005, Reconstructing Old Testament theology, Fortress Press, Minneapolis, MN

Scharff, R.C., 2013, 'Becoming a philosopher: What Heidegger learned from Dilthey, 1919-1925', British Journal for the History of Philosophy 21(1), 122-142. http:// dx.doi.org/10.1080/09608788.2012.689753

Thiselton, A.C., 1980, The two horizons, Pater Noster, Exeter.

Troeltsch, E., 1913, s.v. 'Historiography', in J. Hastings (ed.), Religion and ethics, pp. 716-730, T\&T Clark, Edinburgh.

Troeltsch, E., 1922, 'Über historisch und dogmatisch Methode in der Theologie', in E. Troeltsch (Hrsg.), Gesammelte Schriften II, pp. 729-753, JCB Mohr, Tübingen.

Von Harnack, A., 1908, Das Wesen des Christentums, Heinrichsche Buchhandlung, Leipzig. 